\title{
STUDI PENDAHULUAN PENGEMBANGAN ALAT PIROLISIS SAMPAH PLASTIK POLIPROPILENA (PP) MENGGUNAKAN DRUM SISA PAKAI
}

\author{
Oleh: Rahmanpiu
}

\author{
Dosen Jurusan Pendidikan Kimia FKIP UHO \\ Email : rahmanpiu.fkip@uho.ac.id
}

\begin{abstract}
Abstrak. Sampah plastik PP dihasilkan dari plastik minuman dalam kemasan, jumlahnya melimpah sehingga menimbulkan pencemaran lingkungan. Salah satu metode untuk mengurangi sampah PP adalam metode termal (Pirolisis). Penelitian ini bertujuan untuk mengembangkan alat pirolisis sampah plastik PP dengan bahan yang mudah diperoleh dan ramah lingkungan. Metode digunakan adalah eksperimen melalui tahapan desain, pembuatan alat pirolisis dan uji coba alat pirolisis. Hasil yang diperoleh menunjukkan dari tiga Tipe alat pirolisis yang dikembangkan Tipe 2 dengan kondisi sampel yang bersih memungkinkan utk dikembangkan lebih lanjut. Pirolisat yang dihasilkan didestilasi dan diperoleh bahan bakar cair sebesar 30-41\%, bahan padat yang mudah terbakar sebanyak $30-40 \%$ dan gas yang tidak terkondensasi sekitar $20 \%$. Gas buang yang dihasilkan selama pirolisis Tipe 3 tidak berbau dibandingkan Tipe 1 dan Tipe 2.
\end{abstract}

Kata Kunci : Alat pirolisis, pirolisat, destilasi, plastik PP

\section{PENDAHULUAN}

Sampah plastik merupakan bahan kimia sintetik dari kegiatan manusia seperti sampah rumah tangga dan industri yang tidak dimanfaatkan lagi, apabila masuk ke lingkungan menyebabkan dampak negarif terhadap kekhasan fisik, kimia, biologis dan estetis lingkungan (Connel dan Miller, 1989). Sampah plastik terus bertambah baik dari jumlah maupun jenisnya seiring dengan meningkatnya ; konsumsi, pendapatan dan kepadatan penduduk (World Bank, 2012);

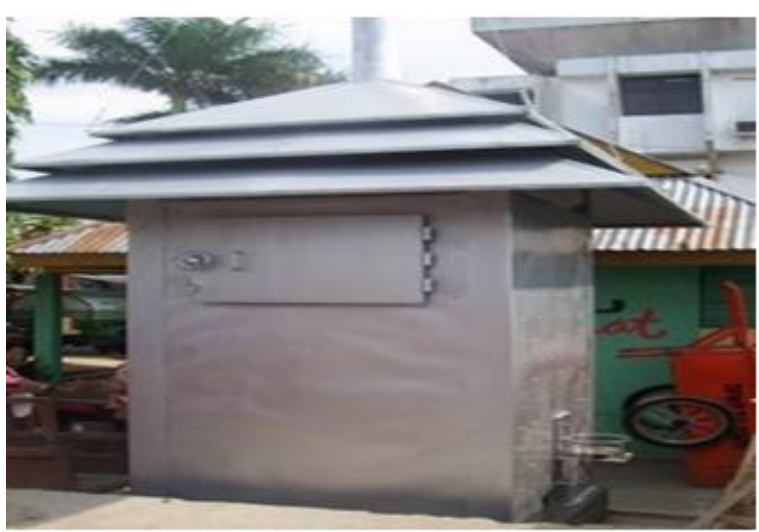

Gambar 1a. Alat pembakaran sampah lincenerator. populasi dan gaya hidup (El Haggar, 2007); kualitas dan kuantitas limbah (Setyowati dkk 2014).

Pengelolaan sampah plastik saat ini masih terbatas pada pengumpul barang bekas atau dibuang bersama sampah organik. Sampah plastik di lingkungan menyebabkan pencemaran tanah dan air. Berdasarkan studi literatur beberapa alat pengolahan sampah plastik/sampah padat ditunjukkan pada Gambar 1a-1d.

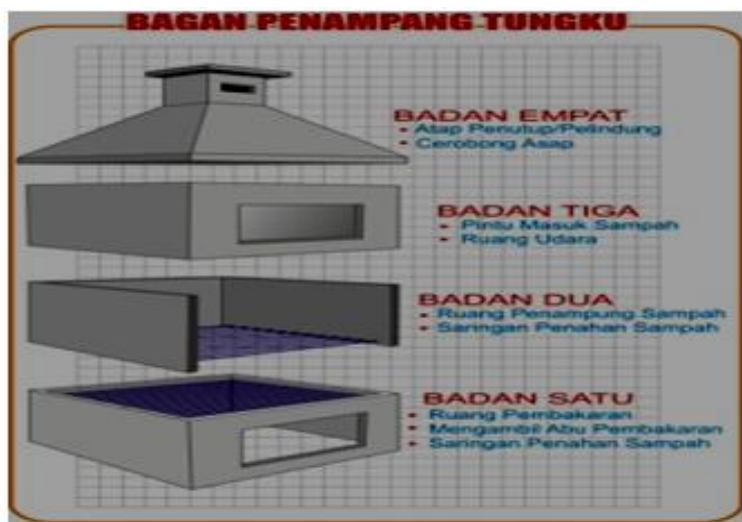

Prinsip kerja : sampah padat mengalami penguraian selama pembakaran menjadi abu, 
asap atau gas buang ke lingkungan Kelebihan

: mengolah sampah dalam jumlah besar tanpa pemilahan, abu dimanfaatkan untuk pertanian

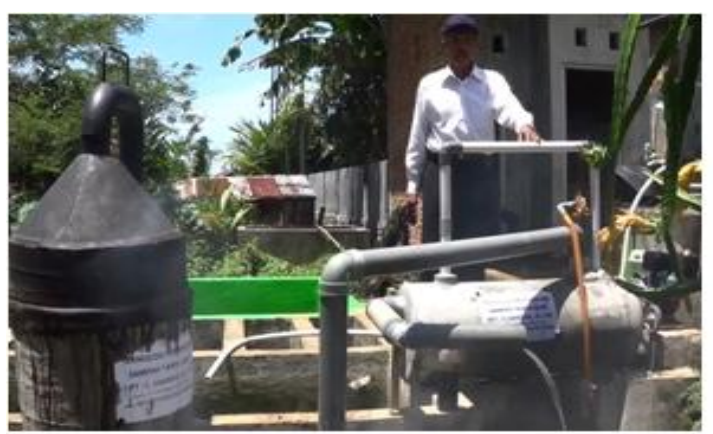

Gambar 1b. Alat pembakaran sampah tanpa asap. Prinsip kerja: Pembakaran sampah menjadi abu, tar dan asap larut dalam air berlangsung secara kontinue dengan bantuan motor listrik. Kelebihan : Pembakaran dapat berlangsung cepat tanpa pemilahan, dioksin, dan industri. Kekurangan gas buang seperti dioksin, furans dan debu-debu berbahaya dilepaskan ke lingkungan.

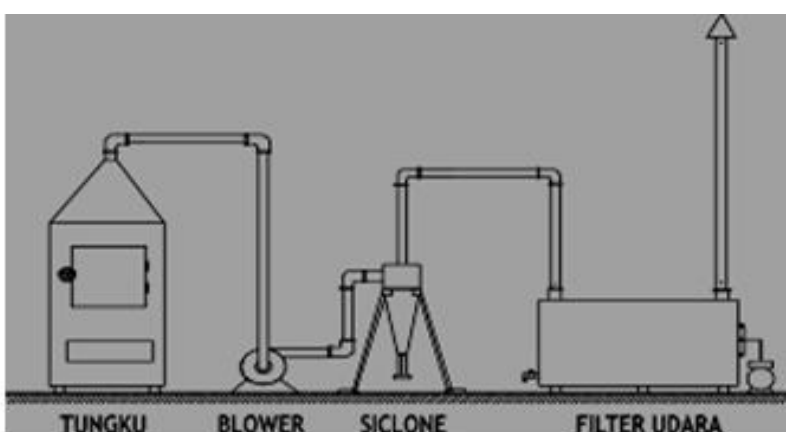

furan dan debu-debu berbahaya diminimalkan melalui filter, gas yang tidak larut di lepas ke lingkungan. Kekurangan : air sebagai filter bahan kimia berbahaya bila dibuang ke lingkungan dapat menimbulkan pencemaran lingkungan.

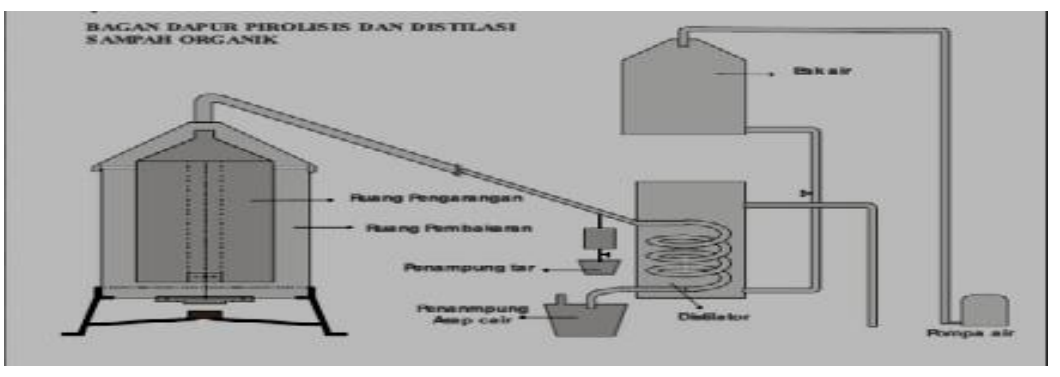

Gambar 1c. Alat pirolisis sampah organik/anorganik (plastik). Prinsip kerja : Sampah mengalami penguraian secara termal melalui pembakaran secara tidak langsung menghasilkan tar, asap cair, arang. Kelebihan : membutuhkan biomassa atau bahan bakar selama pirolisis, gas yang dapat terkondensasi

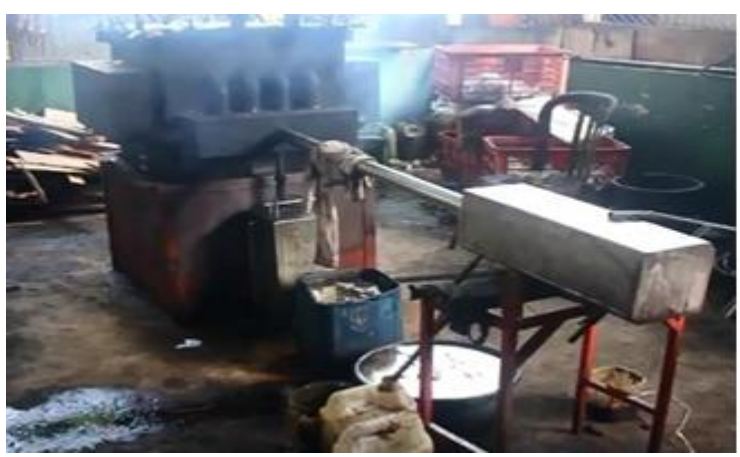

berupa cairan yang dapat dimanfaatkan dan dikaji lebih lanjut. Kelemahan : membutuhkan bahan bakar tambahan dan wadah pembakaran mudah korosif.

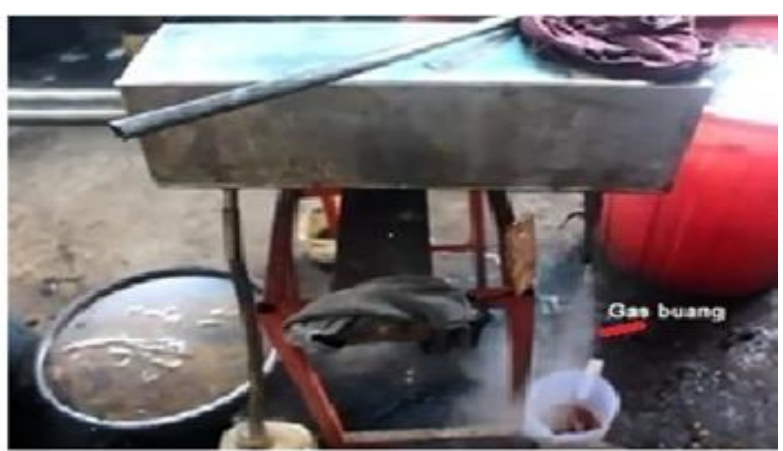


Gambar 1d. Alat pirolisis sampah anorganik (plastik). Prinsip kerja : Sampah plastik mengalami penguraian secara termal menghasilkan bahan organik yang mudah terbakar. Kelebihan : mudah digunakan oleh masyarakat dan dilengkapi dengan sistem kontrol suhu. Kelemahan : Menghasilkan gas berbahaya yang bersifat karsinogen (tanda panah merah).

Berdasarkan studi literatur pada Gambar 1a-1d menunjukkan bahwa pengolahan sampah padat plastik ataupun sampah organik secara termal yang ramah lingkungan terus dikembangkan. Pirolisis sampah anorganik (plastik) untuk menjadi bahan bakar cair masih terus dikembangkan hingga saat ini (Moinuddin et al, 2013) dan bahan bakar cair dapat digunakan sebagai pengganti bahan bakar fosil (Suryo et al, 2011). Untuk membuat alat pirolisis utamanya dengan bahan baku stainles membutuhkan biaya yang besar, sedangkan masyarakat membutuhkan

\section{METODE PENELITIAN}

\section{Desain Penelitian}

Penelitian ini adalah penelitian eksperimen dengan tahapan : (1) Pengembangan alat pirolisis dari drum bekas di mitra usaha Lorong Kencana Kampus Baru UHO Kelurahan Lalolara Kecamatan Kambu Kota Kendari (2) uji coba pirolisis sampah plastik, pemurnian peralatan yang murah dan mudah didapat tetapi memiliki kualitas yang sama dengan alat pirolisis dengan bahan baku stainless steel. Oleh karena itu, salah satu bahan yang mudah didapat dan murah adalah drum. Disamping mudah di dapat bentuknya yang slinder sangat memungkinkan untuk dibuat menjadi alat pirolisis. Berkaitan dengan hal tersebut, peneliti mengembangkan alat pirolisis berbahan baku drum. Alat pirolisis yang dikembangkan dalam penelitian ini mengikuti konsep penguraian dan kondensasi baik pada pirolisis sampah organik dan anorganik secara termal. Prinsip penguraian menggunakan pendekatan metode destruksi (pengabuan) bahan organik dan pemisahan menggunakan metode destilasi. Adapun tujuan penelitian ini adalah mengembangkan dan menguji alat pirolisis berbahan drum serta mendeskripsikan hasil prirolisis.

dan analisis sifat fisik dan kuantitas minyak hasil pirolisis sampah plastik.

\section{Peralatan}

Peralatan yang digunakan adalah drum bekas untuk wadah pirolisis, pipa galvanis 2 inci untuk kondensor, limbah tabung freon untuk memaksimalkan kondensasi, botol kaca untuk penampung kondensat, 
termometer IR (Infra Red) satu set alat destilasi sederhana, kertas saring, batang pengaduk dan corong kaca.

\section{Bahan kimia}

Bahan yang digunakan adalah sampah plastik (polipropilena), aluminium foil, kertas saring, biomassa.

\section{Prosedur Penelitian}

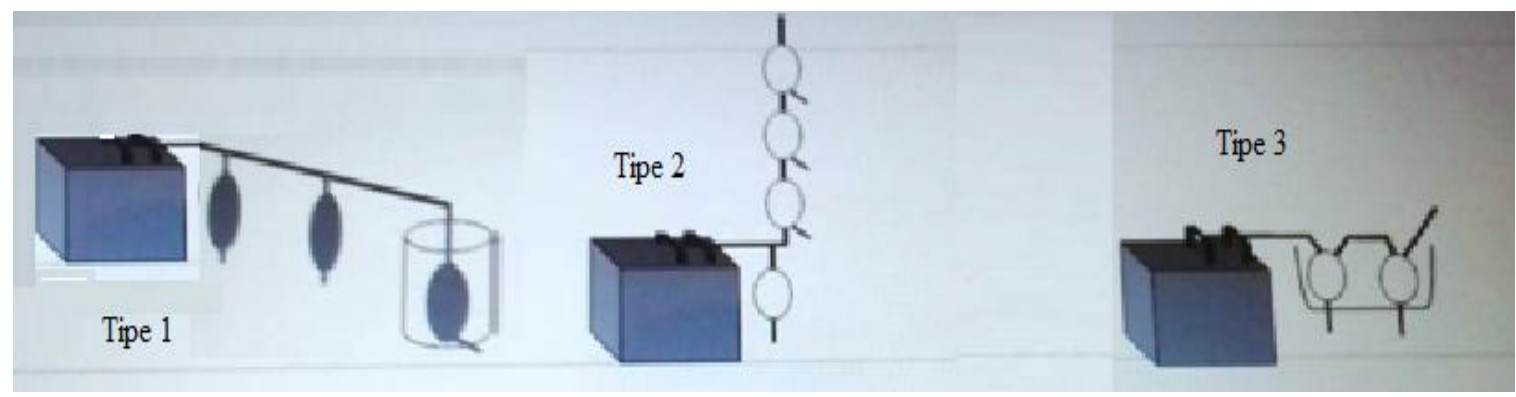

Gambar 2. Desain alat pirolisis

\section{b. Tahap II. Uji Coba Pirolisis}

Pada tahap ini dilakukan dengan kondisi sampel yang berbeda. Alat Pirolisis Tipe 1 dan Tepi 2 sampel plastik masih bercampur air sedangkan Tipe 3 menggunakan sampel plastik yang sudah dikeringkan. Pada Tipe 1 dan Tipe 2 sampel sampah plastik masih masih bercampur air. Cara ini ditempuh untuk mempercepat proses pengolahan plastik secara pirolisis sebab bila dikeringkan membutuhkan perlakukan dan waktu yang relatif lama untuk diproses. Sedangkan pada Tipe 3 sampel plastik digunakan dallam keadaan kering. Dalam penelitian ini sebanyak $6,5 \mathrm{~kg}$ sampah plastik yang sudah bersih polipropilen dipotong kecilkecil $(2-3 \mathrm{~cm})$, kemudian dimasukan ke a. Tahap I. Pengembangan Alat Pirolisis

Tahap pengembangan alat pirolisis melalui kajian literatur pada Gambar 1c-1d kemudian dikembangkan menggunakan drum seperti pada Gambar 2. Keunggulan dan kelebihan masing-masing Tipe di Tunjukkan Pada Tabel 1. 
kapas dengan mengunakan pompa vacum tekanan rendah dengan kecepatan 20 $\mathrm{mL} /$ menit. Kemudian sebanyak $100 \mathrm{~mL}$ filtrat didestilasi pada suhu $60-180{ }^{\circ} \mathrm{C}$ (Thahir dan Alwathan, 2014). Kuantitas minyak hasil pemurnian dinyatakan sebagai rendemen.

\section{HASIL DAN PEMBAHASAN}

Berdasarkan hasil penelitian desain dan uji coba alat pirolisis masing-masing $6,5 \mathrm{~kg}$ sampah plastik jenis polipropilena ditunjukkan pada Tabel 1.

Tabel 1. Desain dan prinsip kerja Tipe Alat Pirolisis Plastik yang dikembangkan serta karakteristik minyak hasil pirolisis

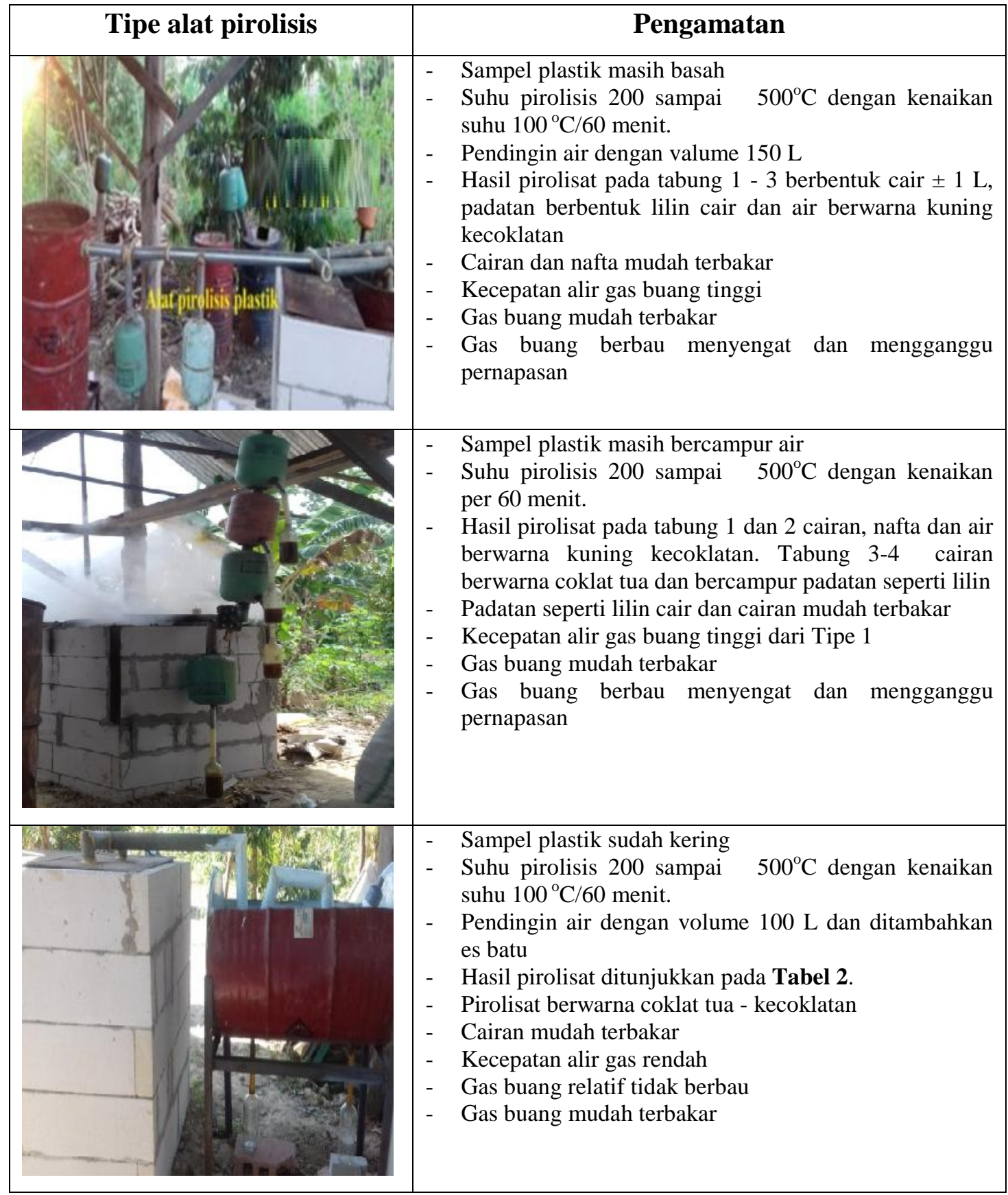


Dari ketiga Tipe alat pirolisis uji lanjut hanya dilakukan pada Tipe 3. Alat pirolisis Tipe 1 dan Tipe 2 tidak dilanjutkan karena kurang efektif dan adanya gas buang yang relatif besar serta menimbulkan pencemaran udara yang mengganggu pernapasan bagi manusia. Alat pirolisis Tipe 1 dan 2 korosif selama pirolisis dibandingkan Tipe 3. Selanjutnya hasil pirolisat Tipe 3 ditunjukkan pada Tabel 2.

Tabel 2. Pirolisat plastik Polipropilena dengan (Alat Pirolisis Tipe 3)

\begin{tabular}{ccccc}
\hline No & $\begin{array}{c}\text { Massa Plastik } \\
(\mathbf{K g})\end{array}$ & $\begin{array}{c}\text { Suhu Tungku } \\
\text { Pirolisis }\left({ }^{\circ} \mathrm{C}\right)\end{array}$ & $\begin{array}{c}\text { Jumlah Minyak Hasil pirolisis (mL) } \\
\text { Tabung I }\end{array}$ & Tabung II \\
\hline 1 & & Pirolisis $200{ }^{\circ} \mathrm{C}$ & - & - \\
2 & & Pirolisis $300{ }^{\circ} \mathrm{C}$ & 145 & - \\
3 & 6,5 & Pirolisis $400{ }^{\circ} \mathrm{C}$ & 240 & 1 \\
4 & & Pirolisis $500{ }^{\circ} \mathrm{C}$ & 1075 & 45 \\
5 & & Pirolisis $>540{ }^{\circ} \mathrm{C}$ & 1685 & 90 \\
\hline
\end{tabular}

Sumber : Hasil Penelitian (Iksan dkk., 2018)

Berdasarkan Tabel 2 tampak bahwa pirolisat meningkat dengan naiknya suhu. Kuantitas terbanyak diperoleh pada Tabung I walaupun tabung II juga meningkat. Hal ini menunjukkan bahwa komponen-komponen penyusun plastik polipropilena mengalami degradasi atau penguraian secara termal pada suhu tinggi (Gambar 2).Temuan ini mendukung penelitian Mustofa dan Zaenuri (2014)

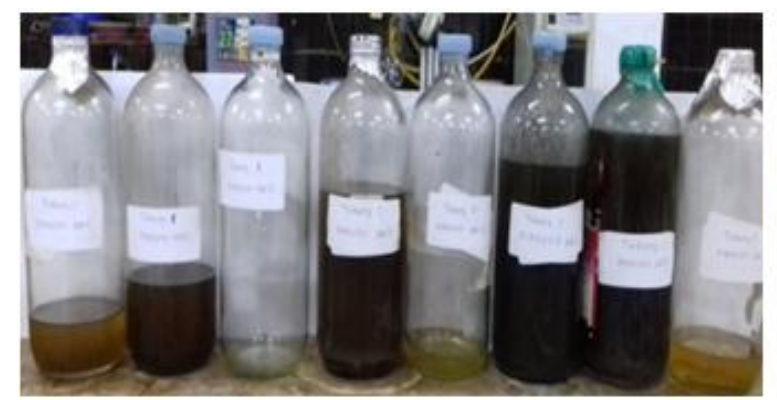

bahwa pada suhu suhu $200{ }^{\circ} \mathrm{C}$ belum ada fraksi minyak pirolisis plastik. Hal ini menunjukkan bahwa komponen plastik pada suhu $200^{\circ} \mathrm{C}$ masih stabil terhadap pemanasan. Namun demikian, proses pemecahan komponen plastik semakin tinggi dengan naiknya suhu. Menurut Pei dkk., (2013) jumlah minyak pirolisis dihasilkan semakin besar dengan bertambahnya suhu pirolisis.

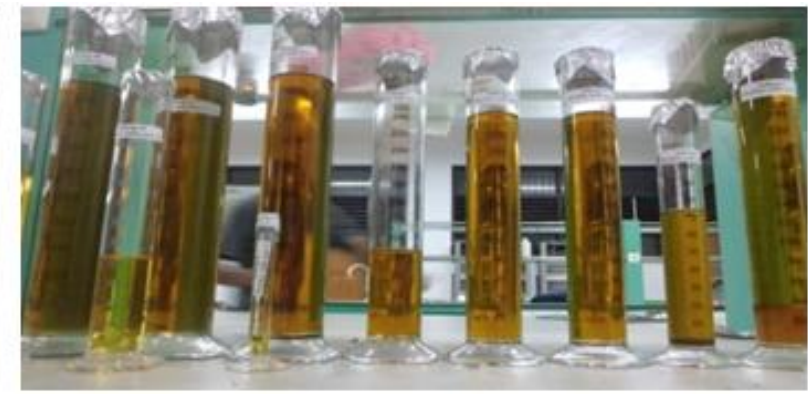

Gambar 2. Pirolisat sebelum (kiri) dan sesudah (kanan) penyaringan

Selanjutnya destilasi dan uji sifat fisik Hasil destilasi ditunjukkan pada Tabel 3. dilakukan pada Tabung I. Jumlah vollum yang reatif besar memungkinkan untuk uji lanjut. 
Tabel 3. Volume destilat minyak hasil pirolisis plastik polipropilena Tabung I

\begin{tabular}{cccccc}
\hline No & $\begin{array}{c}\text { Suhu Tungku } \\
\text { Pirolisis }{ }^{\mathbf{0}} \mathbf{C}\end{array}$ & $\begin{array}{c}\text { Volume } \\
\text { Awal (mL) }\end{array}$ & $\begin{array}{c}\text { Volume Akhir } \\
\text { /destilat (mL) }\end{array}$ & $\begin{array}{c}\text { Residu } \\
\text { (gram) }\end{array}$ & $\begin{array}{c}\text { Persen } \\
\text { destilat } \\
(\%)\end{array}$ \\
\hline 1 & 300 & 100 & 41 & 34,7803 & 41 \\
2 & 400 & 100 & 43 & 35,8848 & 43 \\
3 & 500 & 100 & 42 & 40,6841 & 42 \\
4 & $\geq 540$ & 100 & 32 & 43,9373 & 32 \\
\hline
\end{tabular}

Sumber : Hasil Penelitiaan (Iksan, dkk. 2018)

Berdasarkan Tabel 3 tampak bahwa terbakar. Di samping padatan selama hanya $30-41 \%$ minyak pirolisis yang dapat diperoleh dari setiap $\mathrm{kg}$ sampel destilasi juga dihasilkan gas yang tidak plastik polipropilena. Sisanya berbentuk terkondensasi sekitar 20\%. Hasil destilasi residu berbentuk padat yangmudah
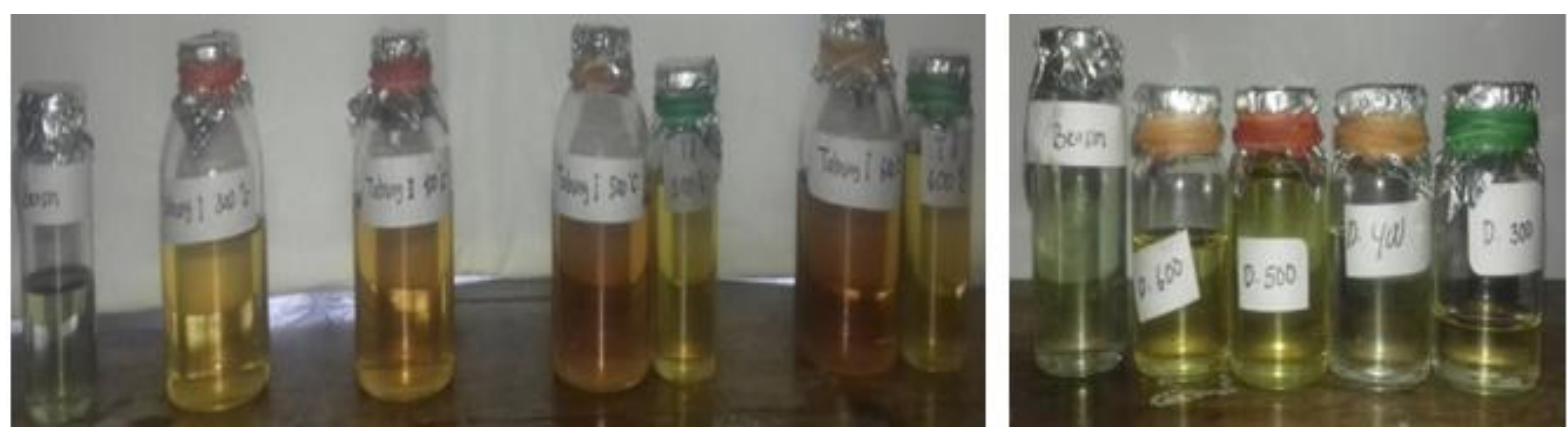

Gambar 2. Warna pirolisat sebelum (kiri) dan sesudah (kanan) destilasi

\section{KESIMPULAN}

Berdasarkan hasil penelitian ini dapat disimpulkan bahwa alat pirolisis sampah plastik dapat dikembangkan dengan memanfaatkan material di lingkungan (drum) dengan menerapkan prinsip destilasi sehingga ramah lingkungan. Bahan bakar cair yang dihasilkan dari pirolisis sampah plastik PP mencapai 30-41\%, bahan bakar padat $30-40 \%$ dan sekitar $20 \%$ gas yang tidak terkondensasi.

\section{Saran}

Alat pirolisis plastik PP dari drum perlu disempurnakan dengan mengatur jarak kondensor tabung 1, tabung 2 dan tabung 3 . Pada tabung 3 dimasukkan kedalam pendingin yang ditambahkan es untuk memaksimalkan kondensasi. Gas buang yang dihasilkan selama pirolisis dan tidak terkondensasi dapat ditampung dalam penampung gas yang dilengkapi dengan lubang penguapan sehingga memungkinkan pirolisis berjalan secara kontinu. 
Pirolisat perlu dilakukan uji lanjut sehingga diperoleh informasi sifat fisikokimia minyak hasil pirolisis sehingga dapat diproduksi sebagai bahan bakar cair yang murah atau padat yang ramah lingkungan.

\section{DAFTAR PUSTAKA}

Basu, P., Biomass Gasification and Pyrolysis Practical Design and Theory. 2010. Published by Elsevier Inc., The Boulevard, Langford Lane Kidlington, Oxford, OX5 1GB, UK.

Iksan, Ratna dan Rahmanpiu, 2018. Pemisahan Fraksi Minyak Hasil Pirolisis Sampah Plastik Polipropilena (PP) dengan Metode Destilasi. Hasil Penelitian yang belum dipublikasikan Jurusan Pendidikan Kimia FKIP.

Moinuddin, S., Rashid, M.M., Rahman, M.S., dan Molla. M. 2012. Conversion of Low Density Polyethylene (LDPE) and Polypropylene (PP) Waste
PlastiksInto Liquid Fuel Using Thermal Cracking Process. British Journal of Environment and Climate Change. 2012. pp 1-11

Mustofa K.D dan Fuad Zainuri. 2014. Pirolisis Sampah Plastik Hingga Suhu $900{ }^{\circ} \mathrm{C}$ Sebagai Upaya menghasilkan Bahan Ramah Lingkungan. Jurnal Simposium Nasional RAPI XIII.

Pei, T., Xiao-bo, M., De-zhen, C., \& Hai, W. (2013). Pyrolysis of waste plastic : Effect of Heating Rate on Product Yields and Oil Properties. Journal Advanced Materials Research, Vol.666, pp 1-10.

Suryo A.W., Adityo. (2011). Studi Sifat Minyak Pirolisis Campuran Sampah Biomassa dan Sampah Plastik Polypropylene (PP). Universitas Sebelas Maret. Surakarta.

Thahir, R., dan Alwathan. 2014. Pengambilan Fraksi Ringan Produk Hasil Pirolisis Limbah Plastik Jenis Polipropilene (Pp) Dengan Metode Destilasi Fraksionasi Bubble Cap. Samarinda : Tehnik Kimia Politeknik. 